\title{
HUBUNGAN OBESITAS SENTRAL DENGAN KEJADIAN DIABETES MELLITUS TIPE II
}

\author{
Nova Nurwinda Sari* \\ *Program Studi Keperawatan Universitas Mitra Indonesia \\ E-mail: nova_sari@umitra.ac.id
}

\begin{abstract}
Penyakit Diabetes Mellitus (DM) menempati urutan pertama dari jenis penyakit endokrin dan urutan ke delapan untuk urutan penyakit tidak menular. Salah satu faktor yang dapat berkontribusi adalah kejadian obesitas yang juga meningkat.Tujuan penelitian adalah untuk mengetahui hubungan obesitas sentral dengan kejadian Diabetes Mellitus Tipe II. Jenis penelitian ini adalah kuantitatif dengan pendekatan case control. Populasi adalah seluruh penderita DM yang berobat di salah satu rumah sakit di Kota Metro pada bulan Januari-Juni 2017 sebanyak 62 orang. Analisis data menggunakan uji statistik Chi-square $\left(\mathrm{X}^{2}\right)$. Hasil penelitian dengan uji chi-square diperoleh $p$-value 0,000 ( $p$-value $\leq 0,05$ ), ada hubungan yang signifikan antara obesitas sentral dan non obesitas sentral dengan kejadian Diabetes Mellitus Tipe II di Rumah Sakit Mardi Waluyo Metro tahun 2017.Diharapkan hasil penelitian dapat digunakan sebagai tambahan pengetahuan dan wawasan responden tentang cara pencegahan obesitas sentral,sekaligus sebagai bahan masukan atau sumber data penelitian selanjutnya.
\end{abstract}

Kata Kunci: Obesitas sentral, Diabetes Mellitus Tipe II

\section{LATAR BELAKANG}

Diabetes Mellitus merupakan kerusakan metabolisme dengan ciri hiperglikemi yang berkaitan dengan ketidakseimbangan metabolisme karbohidrat, lemak serta protein yang disebabkan oleh penurunan sekresi insulin atau penurunan sensitivitas insulin maupun keduanya serta dapat menyebabkan komplikasi kronis mikrovaskular, makrovaskular dan neuropati (Yuliana Elin, 2009). Komplikasi tersebut bisa membahayakan bagi tubuh penderitanya apabila tidak ditangani dengan baik, seperti gagal ginjal, retinopati diabetik, ulkus diabetes melitus serta hipertensi yang berbahaya bagi tubuh. Diabetes Mellitus juga salah satu penyakit yang telah menjadi masalah kesehatan global.

Penderita Diabetes Mellitus di dunia mengalami peningkatan dari tahun ke tahun. Data statistik organisasi kesehatan dunia menunjukkan jumlah penderita Diabetes Mellitus di dunia sekitar 194 juta dan diprediksikan akan mencapai 333 juta jiwa tahun 2025 dan setengah dari angka tersebut terjadi di negara berkembang terutama di Indonesia. Di Asia Tenggara terdapat 46 juta jiwa dan diprediksikkan men.ingkat hingga 119 juta jiwa (WHO, 2015).

Berdasarkan data Kemenkes RI (2016), Di Indonesia dari 8,4 juta pada tahun 2016 diperkirakan akan menjadi 21,3 juta pada tahun 2030. Jumlah penderita di Indonesia yang menderita penyakit Diabetes Mellitus Tipe II sebesar 5,7\% dari keseluruhan jumlah penduduk dan $1,1 \%$ diantaranya meninggal dunia karena Diabetes Mellitus Tipe II.

Laporan dari Badan Penelitian dan Pengembangan Kesehatan Kementrian Kesehatan (Riskesdas) tahun 2013 menyebutkan terjadi peningkatan prevalensi penderita diabetes melitus pada tahun 2007 yaitu 1,1\% meningkat pada tahun 2013 menjadi 2,4\%. Sementara itu prevalensi Diabetes Mellitus berdasarkan diagnosis dokter atau gejala pada tahun 2013 sebesar 2,1\% prevalensi yang tertinggi adalah pada daerah Sulawesi Tengah $(3,7 \%)$ dan paling rendah pada daerah Jawa Barat $(0,5 \%)$.

Data Profil Kesehatan Provinsi Lampung Tahun 2016 prevalensi Diabetes Mellitus adalah 0,6\%. Data Riskesdas tersebut menyebutkan bahwa prevalensi penderita Diabetes Mellitus cenderung meningkat pada perempuan dibandingkan 
dengan laki-laki, dimana terjadi peningkatan prevalensi penyakit Diabetes Mellitus sesuai dengan pertambahan umur namun pada umur $\geq 65$ tahun prevalensi Diabetes Mellitus cenderung menurun. Prevalensi Diabetes Mellitus cenderung lebih tinggi bagi penderita yang tinggal di perkotaan dibandingkan dengan di pedesaan.Ditinjau dari segi pendidikan menurut Riskesdas bahwa prevalensi Diabetes Mellitus cenderung lebih tinggi pada masyarakat dengan tingkat pendidikan tinggi (Dinkes Provinsi Lampung, 2016).

Data Dinas Kesehatan Kota Metro prevalensi penderita Diabetes Mellitus tahun 2015 sebesar 3008 per 100.000 penduduk dan meningkat pada tahun 2016 menjadi 4506 per 100.000 penduduk. Sedangkan jumlah penderita Diabetes Mellitus pada tahun 2015 sebesar 43.312 penderita dan meningkat pada tahun 2016 menjadi 46.465 penderita (Dinas Kesehatan Kota Metro, 2016).

Berdasarkan hasil pra-survey yang peneliti lakukan di Rumah Sakit Mardi Waluyo Metro, terjadi peningkatan angka kejadian Diabetes Mellitus.Di Rumah Sakit Mardi Waluyo Metro penyakit Diabetes Mellitus menempati urutan pertama dari jenis penyakit endokrin dan urutan ke delapan untuk urutan penyakit tidak menular. Pada tahun 2013 penderita Diabetes Mellitus sebanyak 811 pasien, meningkat pada tahun 2014 sebanyak 891 pasien dan tahun 2015 pasien Diabetes Mellitus rawat jalan di Rumah Sakit Mardi Waluyo sebanyak 350 pasien. Tahun 2016 terjadi peningkatan penderita Diabetes Mellitus menjadi 487 pasien, sedangkan pada periode Januari-Juni 2017 kejadian Diabetes Mellitus yang tercatat di rekam medis sebanyak 493 kasus. Peningkatan jumlah penderita yang dirawat di Rumah Sakit Mardi Waluyo lebih banyak dibandingkan dengan rumah sakit lain di kota Metro merupakan latar belakang pemilihan Rumah Sakit Mardi Waluyo sebagai tempat penelitian.

Peningkatan kasus Diabetes Mellitus yang tajam banyak terjadi pada masyarakat dengan perubahan pola konsumsi tinggi lemak dan mempunyai kebiasaan aktifitas fisik yang rendah, sehingga meningkatnya kasus overweight dan obesitas.Orang yang kurang gerak cenderung overweight dan obesitas yang kemudian berhubungan dengan terjadinya peningkatan Diabetes Mellitus (WHO, 2013).

Menurut Sutanegara \& Manalu (2006), Obesitas merupakan salah satu manifestasi dari masalah gizi lebih yang terjadi akibat akumulasi jaringan lemak berlebihan, sehingga dapat mengganggu kesehatan. Bila seseorang bertambah berat badannya maka ukuran sel lemak akan bertambah besar dan kemudian jumlahnya bertambah banyak.

Obesitas dapat diukur dengan dengan berbagai cara baik secara laboratorium maupun non laboratorium. Pengukuran yang sering dilakukan adalah pengukuran non laboratorium (pengukuran praktis) dengan mengukur indeks massa tubuh, lingkar pinggang, dan rasio lingkar pinggang panggul untuk memantau status gizi seseorang. Pengukuran praktis merupakan alat atau cara sederhana untuk memantau status gizi seseorang karena praktis dan murah dalam penggunaanya. Obesitas merupakan faktor risiko paling penting terhadap terjadinya Diabetes Mellitus dimana prevalensi Diabetes Mellitus 2,9 kali lebih tinggi pada mereka dengan status overweight (Arora, dkk 2007).

Menurut Gill (2012), Obesitas berhubungan kuat dengan Diabetes Mellitus terutama Diabetes Mellitus Tipe II dan merupakan faktor risiko independen bagi dyslipidemia, hipertensi dan penyakit kardiovaskuler yang selanjutnya sebagai komplikasi dan penyebab utama kematian bagi seseorang yang menderita Diabetes Mellitus Tipe II Orang dengan obesitas memiliki risiko penyakit Diabetes Mellitus lebih besar dibandingkan penyakit lain. Prevalensi Diabetes Mellitus Tipe II sejalan dengan peningkatan prevalensi obesitas, sekitar $80 \%$ orang dengan Diabetes Mellitus Tipe II adalah obesitas.

Hasil penelitian Iskandar (2010) tentang Faktor risiko kejadian Diabetes Mellitus di daerah khusus Ibukota Jakarta 
menunjukkan bahwa orang gemuk (IMT $\geq 25,1)$ memiliki risiko menderita Diabetes Mellitus sebesar 1,7 kali lebih tinggi disbanding orang yang tidak gemuk (IMT 18,5- $\leq 18,4$ ).

\section{METODE}

Jenis penelitian ini adalah kuantitatif dengan desain penelitian case control dengan pendekatan retrospective. Populasi adalah seluruh penderita DM yang berobat di salah satu rumah sakit di Kota Metro pada Bulan Januari-Juni 2017 sebanyak 62 orang dan sampel sebanyak 62 orang. Analisis data menggunakan uji statistik Chi-square $\left(\mathrm{X}^{2}\right)$.

\section{HASIL}

\section{Karakteristik Responden}

Tabel 1: Distribusi Responden Berdasarkan Karakteristik

\begin{tabular}{lcc}
\hline Karakteristik Responden & f & $\%$ \\
\hline Usia : & & \\
usia $\leq 50$ tahun & 5 & 8.0 \\
usia $>$ 50 tahun & 57 & 92.8 \\
\hline Jenis Kelamin : & & \\
Perempuan & 32 & 51.6 \\
Laki - Laki & 30 & 48.4 \\
\hline Lama Menderita DM: & & \\
$\leq 10$ tahun & 34 & 54.8 \\
$>10$ tahun & 28 & 45.2 \\
\hline Jumlah & 62 & 100 \\
\hline
\end{tabular}

Tabel di atas menggambarkan bahwa responden memiliki karakteristik sebagian besar berusia di atas 50 tahun $(92,8 \%)$, berjenis kelamin perempuan $(51,6 \%)$ dan kurang atau sama dengan 10 tahun menderita DM.

\section{Analisis Univariat}

Tabel 2: Distribusi Responden Berdasarkan Kejadian Obesitas

\begin{tabular}{lcc}
\hline \multicolumn{1}{c}{ Kejadian Obesitas } & f & $\%$ \\
\hline Obesitas Sentral & 25 & 40.3 \\
Non Obesitas Sentral & 37 & 59.7 \\
\hline Jumlah & 62 & 100 \\
\hline
\end{tabular}

Tabel di atas menggambarkan bahwa berdasarkan jenis obesitas sebagian besar termasuk golongan non obestitas sentral.

Tabel 3: Distribusi Responden Berdasarkan Kejadian Diabetes Mellitus

\begin{tabular}{lcc}
\hline \multicolumn{1}{c}{ Diabetes Mellitus } & $\mathrm{f}$ & $\%$ \\
\hline Tipe II & 32 & 51.6 \\
Tipe lain & 30 & 48.4 \\
\hline Jumlah & 62 & 100 \\
\hline
\end{tabular}

Tabel di atas menggambarkan bahwa berdasarkan tipe DM responden sebagian besar DM tipe II $(51,6 \%)$.

\section{Analisis Bivariat}

Tabel 4: Hubungan Obesitas Sentral Dengan Kejadian Diabetes Mellitus Tipe II

\begin{tabular}{lcccccc}
\hline \multirow{2}{*}{$\begin{array}{l}\text { Kejadian Obesitas } \\
\text { Sentral }\end{array}$} & \multicolumn{4}{c}{ Kejadian DM } & \multicolumn{2}{c}{ Total } \\
\cline { 2 - 7 } & \multicolumn{3}{c}{ Tipe II } & \multicolumn{1}{c}{ Tipe Lain } & \multirow{2}{*}{ f } & $\%$ \\
\cline { 2 - 7 } & f & $\%$ & f & $\%$ & & \\
\hline Obesitas & 20 & 62.6 & 5 & 16.7 & 25 & 40.3 \\
\hline Tidak obesitas & 12 & 37.5 & 25 & 83,3 & 37 & 59.7 \\
\hline Jumlah & 32 & 100 & 30 & 100 & 62 & 100 \\
\hline p-value & 0,000 & & & & \\
\hline OR 95 \% CI & $8,333(2,516$ & $-27,60)$ & & \\
\hline
\end{tabular}

Hasil uji statistik $p$-value $=0,000(p$ value $<\alpha=0,05$ ) yang berarti ada hubungan obesitas sentral dengan kejadian Diabetes Melitus Tipe II. Kemudian diperoleh OR $=8,333$ (CI 95\%: 2,516 $27,60)$ yang berarti bahwa responden yang mengalami obesitas mempunyai peluang sebesar 8,333 kali mengalami kejadian Diabetes Melitus Tipe II dibandingkan dengan responden yang tidak mengalami obesitas sentral. 


\section{PEMBAHASAN}

\section{Obesitas Sentral}

Menurut Tchernof dan Despres (2013) obesitas sentral didefinisikan sebagai penumpukan lemak dalam tubuh bagian perut. Penumpukan lemak ini diakibatkan oleh jumlah lemak berlebih pada jaringan lemak subkutan dan lemak viseral perut. Penumpukan lemak pada jaringan lemak viseral merupakan bentuk dari tidak berfungsinya jaringan lemak subkutan dalam menghadapi kelebihan energi akibat konsumsi lemak berlebih.Kelebihan energi terjadi ketika seseorang memiliki aktivitas fisik Kurang dan tingginya perilaku sedentari. Selain itu ketidakmampuan jaringan lemak subkutan sebagai penyangga energi berlebih akan menyebabkan produksi lemak yang dapat menumpuk pada bagian-bagian tubuh yang tidak diinginkan, seperti hati, jantung, ginjal, otot, dan kelenjar pancreas.

\section{Diabetes Mellitus}

Menurut Perkeni (2011), Diabetes Mellitus (DM) merupakan suatu kelompok penyakit metabolik dengan karakteristik hiperglikemi yang terjadi karena kelainan sekresi insulin, kerja insulin atau keduaduanya. Perkeni membagi alur diagnosis Diabetes Mellitus menjadi dua bagian besar berdasarkan ada tidaknya gejala khas Diabetes Mellitus.

Sedangkan menurut Price \& Wilson (2011), Diabetes Mellitus merupakan suatu keadaan hiperglikemia menahun yang dapat mengenai seluruh sistem tubuh.Keadaan ini disebabkan oleh karena adanya faktor yang menghambat kerja insulin atau jumlah menurun.Kadar glukosa serum normal adalah $110 \mathrm{mg} / \mathrm{dL}$. Glukosa difiltrasi oleh glomerulus dan hampir semuanya di filtrasi oleh tubulus ginjal selama kadar glukosa dalam plasma tidak melebihi 160-180 mg/dL.

\section{Hubungan Obesitas Sentral dengan Kejadian Diabetes Mellitus Tipe II}

Menurut Sutanegara \& Manalu (2006), obesitas merupakan salah satu manifestasi dari masalah gizi lebih yang terjadi akibat akumulasi jaringan lemak berlebihan, sehingga dapat mengganggu kesehatan. Bila seseorang bertambah berat badannya maka ukuran sel lemak akan bertambah besar dan kemudian jumlahnya bertambah banyak.

Menurut Arora et al. (2007), obesitas dapat diukur dengan dengan berbagai cara baik secara laboratorium maupun non laboratorium. Pengukuran yang sering dilakukan adalah pengukuran non laboratorium (pengukuran praktis) dengan mengukur indeks massa tubuh, lingkar pinggang, dan rasio lingkar pinggang panggul untuk memantau status gizi seseorang. Pengukuran praktis merupakan alat atau cara sederhana untuk memantau status gizi seseorang karena praktis dan murah dalam penggunaanya. Obesitas merupakan faktor risiko paling penting terhadap terjadinya diabetes mellitus dimana prevalensi Diabetes Mellitus 2,9 kali lebih tinggi pada mereka dengan status overweight.

Menurut Gill (2012), obesitas berhubungan kuat dengan diabetes mellitus terutama Diabetes MellitusTipe II dan merupakan faktor risiko independen bagi dyslipidemia, hipertensi dan penyakit kardiovaskuler yang selanjutnya sebagai komplikasi dan penyebab utama kematian bagi seseorang yang menderita Diabetes MellitusTipe II.

Hasil penelitian Naomi H (2012) obesitas sentral sebagai faktor risiko terjadinya pradiabetes di Kabupaten Cimahi, hasil penelitian menunjukkan Variabel yang berpengaruh terhadap prediabetes adalah obesitas sentral $(p=0,041) \quad$ dan hipertensi sistolik $(p=0,041)$.

Berdasarkan uraian di atas, maka menurut peneliti orang dengan obesitas memiliki risiko penyakit Diabetes Mellitus lebih besar dibandingkan penyakit lain. Prevalensi Diabetes Mellitus Tipe II sejalan dengan peningkatan prevalensi obesitas, sekitar $80 \%$ orang dengan Diabetes Mellitus Tipe II adalah obesitas. 


\section{KESIMPULAN}

Berdasarkan hasil penelitian dan pembahasan, maka dapat diambil kesimpulan bahwa dari total 62 responden, sebanyak 37 responden $(59,7 \%)$ tidak mengalami obesitas sentral dan sebanyak 32 responden $(51,6 \%)$ mengalami Diabetes Mellitus Tipe II.Analisis lebih lanjut menyimpulkan ada hubungan obesitas sentral dengan kejadian Diabetes Melitus Tipe II dengan ( $p$-value $=0,000)$.

Berdasarkan kesimpulan di atas, maka disarankan kepada responden untuk meningkatkan pengetahuan dan wawasan untuk dapat mengatur gaya hidup sehingga terhindar dari obesitas yang dapat beresiko meningkatkan Diabetes Mellitus. Sedangkan bagi dinas kesehatan dan jajaran terkait agar dapat memberikan informasi kepada masyarakat luas tentang upaya pencegahan kejadian Diabetes Mellitus Tipe II salah satunya dengan cara mengendalikan.

\section{DAFTAR PUSTAKA}

Arora, M., Koley, S., Gupta, S., et al, 2007.A Study on Lipid Profile And Body Fat in Patients with Diabetes Mellitus. Anthropologist, 9(4):295-8

Dinkes Provinsi Lampung, 2016, Profil Kesehatan Provinsi Lampung, Bandar Lampung.

Dinkes Kota Metro, 2016, Profil Kesehatan Kota Metro, Metro.
Gill, 2012, Diabetic foot ulcers: Prevention, diagnosis and classification. Am Fam Physician, 57(6): 1325-1332

Iskandar, 2010Faktor risiko kejadian Diabetes Mellitus di daerah khususIbukota Jakarta, Jurnal Penelitian.

Kemenkes RI, 2016, Profil Kesehatan Republik Indonesia Tahun 2016, Jakarta.

Naomi H, 2012, Obesitas sentral sebagai faktor risiko terjadinya pradiabetes di Kabupaten Cimahi, Jurnal Penelitian.

Perkeni, 2011, Konsensus Pengelolaan dan Pencegahan Diabetes Melitus Tipe 2 di Indonesia.

Price dan Wilson, 2011, Patofisiologi: Konsep Klinis Proses-.Proses Penyakit, Edisi 6, Volume 1. EGC: Jakarta.

Sutanegara \& Manalu, 2006, Pathogenesis and Pharmacologic Treatment of Obesity: The Role of Energy Regulatory Mechanism. Acta Medica Indonesiana 38; 42-49.

WHO, 2015, Non communicable disease country profiles 2011 WHO global report, World Health Organization, Geneva.

WHO, 2013, Op. Cit, World Health Organization, Geneva

Yuliana Elin, Andrajat Retnosari, 2009. ISO Farmakoterapi. Jakarta : ISFI 